\title{
Labor Law Course Practice Teaching in the Mode of Legal Clinic Aid
}

\author{
Zhao Qing-dong \\ Nanyang Institute of Technology College of Liberal Arts and Law, \\ Henan Nanyang 473000, China
}

\begin{abstract}
- the goal of labor law practice teaching in the mode of legal clinic aid is to cultivate students' practicing lawyer quality. To achieve this goal, law case sources, teachers with rich practice experience and a practical teaching procedure by handling cases are needed. This article takes Nanyang Institute of Technology as an example to discuss the goal of labor law practice teaching and the achievement of the goal.
\end{abstract}

Key words—practice teaching; legal aid by legal clinics; practicing lawyer quality

\section{INTRODUCTION}

In 2003, approved by the Nanyang Municipal Judicial Bureau, Nanyang Institute of Legal Aid Center was established. Since Nanyang Institute of technology 07 version training programs, legal clinics education has always been my School of Law students of an elective course. In response to my school Training applied personnel training objectives, author started to assume the identity of lawyers to handle the actual labor dispute in school legal aid center from 2010. As the starting point, the use of legal clinic practice teaching mode, the practice of labor law shifted from the classroom to the legal services market Frontier Field. Under the Legal Aid Clinic, why does use teaching target labor law practice teaching? How to achieve this kind of project Objects? All are urgent to answer.

\section{II . THE GOAL OF TEACHING PRACTICE UNDER THE LEGAL AID CLINIC MODE}

As the goal of law labor law practice teaching, it is to enhance students' legal thinking ability, improve their use of technology law skills. Regardless of the realization of this kind of case teaching objectives, the drawbacks of expertise, moot court and other means, but its goal set is quite backward.

Common law countries found that the theory lectures can not improve students' legal ability in the education process of law, and thus proposed teaching model of clinical legal education [1]. Clinical Legal Education is an imitation of the way of medical students practice in the clinic directly as lawyers deal with cases. "Committed to developing legal awareness lawyer with the stance, skills and duties at the completion of professional education" [2] . Actually clinical legal education and legal aid are interlinked; their common point is the students mainly directly for the case.

Practice Teaching Mode Clinic for legal aid in China has just flourishing, legal aid agencies at universities is still in the construction period, the goal of teaching practice is not yet clear. Examination of various clinical legal education models and its common law legal aid practice teaching mode of communication, the Legal Aid Clinic practice teaching mode, the target should be defined as "to develop the students' legal career accomplishment." From the relationship between the legal profession and legal education, that the legal profession should have the basic knowledge should be the objectives and requirements of legal education [3] . 
In China, the relationship between the three legal professions is parallel. Based on the demand side of labor, the objectives of law practice teaching should develop a judge, prosecutor, lawyer professionalism. However, we believe that goal unreasonable. First, the legal profession legal profession is more complex, it can be said lawyer vocational skills including other types of legal professional skills [4]. The legal aid clinic practice teaching is to develop the students' lawyer professionalism; the students can reach the legal profession legal professionalism demands. Secondly, labor law legal aid model does not necessarily support the establishment of these objectives. Thus, the objectives are determined : (1) the formation of students' professional lawyer thinking. Including professional lawyer thinking sense of purpose, sense of independence and risk awareness. (2), training students practical skills of professional lawyers. Practical skills of a professional lawyer can be summarized as listening, speaking, reading and writing four aspects, each one has its unique features. (3), enlightenment students' legal ethics.

\section{THE CONDITIONS OF THE LEGAL AID CLINIC MODEL OF LABOR LAW PRACTICE TO IMPLEMENT TEACHING OBJECTIVES}

\section{(1) Teachers requirement}

1, the requirements of teachers for teaching labor law practice Legal Aid Clinic mode, students are subject to control by the practice of the process[5][6]. Teachers should have lawyer professional qualification under legal aid; students are faced with actual cases. Teacher as an observer, mentors, is a basic requirement.

2, the teacher should have a wealth of experience in the legal practice of labor law. Lawyers is a professional activity, legal life is experience. Theoretical knowledge and master the rules of law are only one aspect of the rule of law into practice skills, and experience is essential to guide the practice of teaching in terms of labor law. Teachers have a lack of practical experience is a bottleneck restricting the practice of teaching objectives [4]. College teachers must have much experience.

\section{(2) cases}

In much law school due to fewer case source opportunities for students to participate leads to less motivation for students in clinical legal education. [9] Thus, the practice of teaching labor law Legal Aid Clinic mode, need to be sustained and stable labor disputes as the most primitive "material" for the students so as to improve students' practical legal skills.

The Case source is an important part of the Legal Aid Clinic practice of teaching. But the legal clinic or legal aid agencies of Universities are widespread lack of text Sources[4]. Text source is insufficient [7]. To deepen its students' knowledge and the legal basis for understanding the basic theory has some significance, but it is difficult for students to learn other skills of lawyers, such as fact-finding, communication, defense, negotiation and litigation. [9] These abilities, skills and professionalism, in practice only through exercise, they may be provided with training. [4] The lack of funds seriously hampered the conduct of clinical legal education model to achieve the teaching objectives. [10] In order to overcome less important tendency in the professional training program 09 Nanyang Institute of Jurisprudence, legal aid training, clinical legal education training is professional courses, and set to be six credits.

\section{THE BASIC PROCEDURES UNDER LABOR LAW LEGAL AID PRACTICE TEACHING MODE TO ACHIEVE THE TARGET}

\section{Centralized training before induction}

Students handle actual cases and legal affairs, learning by doing[4]. As a professional practice, students without a corresponding practical experience, it is difficult to get the recognition and trust, although with the presence of students' knowledge of the law.

\section{Students handle the cases}

Students handle the case with the traditional teaching is different, however the Clinical Legal Aid is from the beginning the students as associate counsel to look at. In 
true Real clinic activities, students should shoulder social responsibility like a real legal profession[6]. Thus, this kind of practice teaching mode, students are subject to the status of teachers in guiding students' case handling activities at the core of the practice of teaching. In the formation of students' professionalism the Legal Aid Clinic is to enable students to face the complicated legal dispute, so that students learn from practice lessons and from the failure.

\section{Evaluation}

The teacher is supervisor, instructor status in students' Legal Aid Clinic practice. teachers are as mentors in clinical legal education, the students deal with labor dispute legal assistance activities to evaluate the whole process, the clients stated their reception, qualitative facts, evidence collection, drafting documents, litigation and other activities in the shortcomings and desirable place to encourage students to reflect on mistakes, sum up experience and improve themselves.

\section{REFERENCES}

[1] Qi xishan . Comparison of Chinese and American clinical legal education goals [J]. Education and Professional, 2012 (11): 134-135.

[2] Wang Limin, Mu Xiaoyuan. Clinical Legal Education Research [M]. Shanghai: Shanghai Jiaotong University Press, 2004:

[3] Zhen Zhen. Clinical Legal Education in China [M]. Beijing: Law Press, 2002: 39 .

[4] Wang Juying. Thinking "Clinical Legal Education" localization [J]. Hebei Law, 2005 (3): 84.

[5] Yang Xinxin. Education and Clinical Teaching Method for Law [M]. Beijing: Law Press, 2002: 153

[6] Shi Li . Clinical Legal Education in China Practice [J]. Xinyang Normal University (Philosophy and Social Sciences), 2007 (8): 52.

[7] Li Zhengxin. Law Education "clinical" training - Localization and Clinical Legal Education Dilemma response [J]. Legal Education, 2012 (2): 49.

[8] Tang Yiqun. Docking of Clinical Legal Education and the Law Classroom Teaching [J]. Baicheng Normal University, 2008(4): 107.

[9] Renfan, Hu Yuxia. Law "unmarketable" Countermeasures --- On the Establishment of University Legal Clinic [J]. Heilongjiang Higher Education Research, 2007 (12): 137.

[10] Li Yong. Consideration of clinical legal education in China [J]. Central South University (Social Science Edition), 2006 (3):376.

\section{CONCLUSION}

"Learning by doing" in practice labor law practice teaching mode under the Legal Aid Clinic is to develop the students' labor law lawyers' knowledge and skills. To achieve this goal is a systematic project, which requires teachers, students, schools and other agencies to work together, it need to construct a separate syllabus, rationalize and optimize the process of teaching practice. But most importantly, nothing less than a shooting at the students handled the case. In the traditional mode of education law, law students mainly study the basic theory and knowledge of the law on the books, it is lacking in practical experience. These practices through case studies do not really get by other teaching or moot court actions. 